\title{
PARP1 - Another factor of stemness?
}

\author{
Robaszkiewicz Agnieszka* \\ Department of Environmental Pollution Biophysics, Institute of Biophysics, University of Lodz, Poland
}

The pluripotency of embryonic stem cells, which are capable of unlimited self-renewal and differentiation into every type of cell in the body, is provided by the extensive expression of genes encoding stemness factors, among which the transcription factors such as Sox2, Pou5f1, Nanog are most frequently enumerated [1]. These proteins interact with specific sequences in the regulatory elements of cell typespecific and/or cell cycle regulating genes thereby rescuing cell from the differentiation process. Recent findings have shed the light on DNAinteracting genome guardian - PARP1, which might be considered as another player in the complex stemness game [2].

According to the published data PARP1 together with PARP7 sustains the pluripotency of embryonic stem cell by maintaining the active chromatin configuration (reduced $\mathrm{H} 3 \mathrm{~K} 9 \mathrm{me} 3$ and $\mathrm{H} 3 \mathrm{~K} 27 \mathrm{me} 3$ as well as DNA methylation) at promoters of Nanog, Pou $5 f 1$, Sella and $Z f p 43$ [3]. Thus, the lack of PARP1 favors the repression of pluripotency factors and the enhances retinoic acid-induced ES differentiation into derivatives off all three germ layers in embryoid bodies. Moreover, the reprograming of somatic cells into pluripotent stem cells (iPSCs) requires inter alia PARP1 recruitment to Nanog and Esrrb loci, where functions in the establishement of active chromatin state and facilitates the binding of Oct4 [4]. Another "for" comes from the observation that PARP1 augments expression of the proliferation-promoting fibroblast growth factor - FGF4 directly by the binding to FGF4 enhancer and indirectly by ADP-ribosylating Sox ${ }_{2}$, what results in the dissociation of Sox2 from FGF4 upstream regulatory element in embryonic stem cells [5]. Furthermore, transcription of PARP1 was found to be downregulated during certain types of the differentiation such as myoblasts into myotubes differentiation [6]. The PARP1 repression was associated with the reduction of PCNA expression (marker of cell proliferation) and with the accumulation of myogenin (myogenesisspecific transcription factor). One may think that PARP1 repression may be prerequisite for the cell fate, but such far-reaching idea requires further verification.

Summing up, based on the premises acquired up to date PARP1 meets the criteria to be at least considered as another factor, which determines cell pluripotency and self-renewal.

\section{References}

1. Bilodeau M, Sauvageau G (2006) Uncovering stemness. Nat Cell Biol 8: 1048-1049.[Crossref]

2. Javle M, Curtin NJ (2011) The role of PARP in DNA repair and its therapeutic exploitation. Br J Cancer 105: 1114-1122.[Crossref]

3. Roper SJ, Chrysanthou S, Senner CE, Sienerth A, Gnan S, et al. (2014) ADPribosyltransferases Parp1 and Parp7 safeguard pluripotency of ES cells.Nucleic Acids Res 42: 8914-8927.[Crossref]

4. Doege CA, Inoue K, Yamashita T, Rhee DB, Travis S, et al. (2012) Early-stage epigenetic modification during somatic cell reprogramming by Parp1 and Tet2. Nature 488: 652-655.[Crossref]

5. Gao F, Kwon SW, Zhao Y, Jin Y. (2009) PARP1 poly (ADP-ribosyl)ates Sox2 to control Sox 2 protein levels and FGF4 expression during embryonic stem cell differentiation. $J$ Biol Chem 284: 22263-22273.[Crossref]

6. Oláh G, Szczesny B, Brunyánszki A, López-García IA, Gerö D1, et al (2015) Differentiation-Associated Downregulation of Poly(ADP-Ribose) Polymerase-1 Expression in Myoblasts Serves to Increase Their Resistance to Oxidative Stress. PLoS One 10: e0134227.[Crossref]
Copyright: (C)2016 Agnieszka R. This is an open-access article distributed under the terms of the Creative Commons Attribution License, which permits unrestricted use, distribution, and reproduction in any medium, provided the original author and source are credited.
Correspondence to: Robaszkiewicz Agnieszka, Department of Environmental Pollution Biophysics, Institute of Biophysics, University of Lodz, Pomorska 141/143, 90-236 Lodz, Poland, E-mail: robaszkiewicz.agnieszkaz@gmail.com

Received: July 25, 2016; Accepted: August 08, 2016; Published: August 08, 2016 